\title{
A Cell of Their Own: The Incarceration of Women in Late Medieval Italy
}

A

rare consensus among scholars working across disciplines, regions, and periods concerns women's seemingly perennial marginality and gross underrepresentation in criminal processes. Explanations differ, running the gamut from women's law-abiding nature or their superior talent for concealing crime, to a lack of motives combined with limited opportunities, to the hegemony of patriarchal, gender-biased systems skewing detection, conviction, and sentencing patterns. ${ }^{1}$ Whatever the case, it has shaped a common view of the prison, the cornerstone of modern penology, as "a no-woman's-land" (Carlen 1983, 155) or, alternatively, as "no place for a lady" (James 2007).

Historically, however, the relations between women's involvement in crime and their presence and handling in prisons follow a complex pattern (Feeley and Little 1991; Feeley and Aviram, forthcoming). Female offenders composed a small minority among inmates wherever and whenever prisons have left pertinent records, from their initial proliferation in late medieval Europe, through the early modern period, and to the present. ${ }^{2}$ Yet, throughout the prison's long history, women's marginality posed far more than a bureaucratic nuisance fostering apathy and neglect. Rather, female inmates' presence, while modest, was often considered pernicious and at times required more resources per capita, especially when fully segregated,

My thanks to Anne Lester, Mieke Aerts, Carol Lansing, Shelly Makleff; seminar participants in Amsterdam, Manchester, Gent, Jacksonville, and Canterbury; and the anonymous reviewers for Signs. This essay began life as an inaugural lecture at the University of Amsterdam, delivered on November 19, 2010.

${ }^{1}$ See Pollak (1950), Adler (1975), Simon (1975), Conway and Bogdan (1977), Teilmann and Landry (1981), Marshall (1983), Rafter (1983, 1985), Lesselier (1984), Chesney-Lind (1986), South and Messner (1987), Hagan, Simpson, and Gillis (1988), Zedner (1991), Walker (1994), Shapiro (1996), Gradowicz-Pancer (2002), Eisner (2003), and Belknap (2007).

${ }^{2}$ On women's incarceration in medieval Europe, see Pugh (1968), Peters (1995), Dean (2001), Dunbabin (2002), Claustre (2007), and Geltner (2008d); on the early modern period, see Spierenburg (1991); on the present day, see Kruttschnitt and Gartner (2003), Belknap (2007), and Chen and Einat (2010).

[Signs: Journal of Women in Culture and Society 2013, vol. 39, no. 1]

(c) 2013 by The University of Chicago. All rights reserved. 0097-9740/2013/3901-0002\$10.00 
if similar conditions of incarceration to those of men were to be observed (Dodge 1999). ${ }^{3}$

The tragic asymmetry between male and female prisoners reached a high point in the early nineteenth century in both Europe and the United States. As one prison chaplain famously remarked in 1833: "To be a male convict in this prison would be quite tolerable; but to be a female convict, for any protracted period, would be worse than death" (in Rafter 1983, 135). Historians have done much to corroborate this stock quotation, which purports to capture the impetus for the proliferation of women's prisons in the antebellum United States as a reaction to the dire state of local penitentiaries there and following similar trends across the Atlantic. Yet what such accounts often imply is that reformers such as Elizabeth Fry (1780-1845) in England and Dorothea Dix (1802-87) in the United States challenged perennial wrongs. For modern scholars tend to assume that the premodern prison, in Simona Trombetta's words, was a "Babylon" $(2004,12)$ and inmate conditions in it must have been, in the opinion of Meda Chesney-Lind, employing the ultimate pejorative, "medieval" (1986, 93).

The ameliorative assumptions embedded in such accounts have already been exposed by Lucia Zedner (1991), using the example of Victorian England, and by Pieter Spierenburg (1991) for early modern Europe. What these and other works have shown is that, from a broader historical perspective, attitudes toward female inmates fluctuated rather than remained steady, and cannot be characterized as simply ignorant or continuously neglectful prior to modern reforms. Women neither wallowed in some deplorable state until their needs finally became apparent to a number of sympathetic, enlightened observers, nor did their conditions continuously improve since the implementation of modern reforms.

The present article joins the challenge to an ameliorist view of prison history and of female incarceration in particular by expanding the debate geographically into Italy and chronologically into the fourteenth century, when prisons first began to proliferate (Geltner 2008d). While Italy shares certain tendencies with other regions that spawned prisons during the same period, the peninsula's extant documentation is often superior, affording a close view of the first female wards in several urban prisons. These records help question the explanatory value of a link between quantity and quality in the history of women's imprisonment: if for centuries women

\footnotetext{
${ }^{3}$ In present-day Florida, for example, female inmates are 60 percent more expensive to maintain than male inmates, and their health-related costs are nearly four times as high. See http://www.dc.state.fl.us/pub/annual/0910/budget.html.
} 
remained a minority among inmates, and yet attitudes toward them kept changing, it is worth looking beyond statistics to identify what is shaping their incarceration experiences, or else interrogate what underlay those numbers to begin with.

In what follows, I will first account for medieval Italian women's marginality in prisons by identifying forces that pushed them toward and pulled them away from these institutions, and the extent to which these forces changed with the development of female wards within centralized urban facilities. I will then move to sketch the social profile of female inmates, mainly drawing on the records of Le Stinche, the Florentine municipal prison, during its first century of activity, circa 1300-1400. This section will also discuss women's experiences of incarceration, both independently and as compared with those of their male counterparts. The conclusion will situate medieval practices within a revised and broader history of female incarceration.

\section{Medieval female offenders: Statistics and sources}

Criminal statistics betray a reluctance to see medieval women as genuine offenders or to punish them as such. ${ }^{4}$ Officialdom's tendency to write female culprits out of social memory boded well for keeping premodern prisons male, an attitude also reflected in art and literature: with the rare and partial exception of the early Christian martyr Perpetua (Musurillo 1972, 106-31), there are virtually no accounts or even depictions of late-antique or medieval female inmates outside the so-called consolatio genre (stemming from Boethius's Consolation of Philosophy, which is set in a prison) or beyond the allegorical and courtly love traditions, such as Jean Froissart's La prison amoureuse (Froissart 1974; see also Means 1972; Margolis 1978). Nor are there-inquisitorial depositions notwithstanding - any writings composed by or even attributed to imprisoned women throughout the onethousand-year period commonly known as the Middle Ages, even as vernacular literacy spread and prisons proliferated. ${ }^{5}$

To judge by criminal statistics, art, and literature, then, the late-medieval prison should have been a no-woman's land, with an attendant disregard for women's needs. And yet this is precisely when female offenders were ushered more systematically than ever before through secular justice systems and incarcerated in the centralized facilities that were ostensibly built

\footnotetext{
${ }^{4}$ See Hanawalt (1974), Given (1977), Cohen (1980, 312), Cohn (1996, 16-38), Neville (1998), Sims (2005), and Dean (2008).

${ }^{5}$ See Menage (1978), Kasprzyk (1988), Boffey (1991), Meneghetti (1992), Summers (2004), and Mooney and Arn (2005, 1-12).
} 
for men. ${ }^{6}$ Furthermore, prisons' layout and their regimes were designed with a modicum of awareness of women's needs, or at least what men thought these might be. If women were being ignored, they were ignored by design.

The earliest provisions for the creation of prisons, which surface in Italy and elsewhere in the late thirteenth century, stress wardens' obligation to distinguish among categories of inmates and to set them physically apart (Geltner 2008d, 1-27). Known today as prisoner classification, the process constitutes a topic of major importance in modern penology (Wright 1988; Hutchinson, Keller, and Reid 2009). True, medieval prison administrations were far more rudimentary than their modern heirs, designed as they were to supervise custodial (i.e., pretrial or preexecution) and coercive (i.e., debt) incarceration rather than long-term penal imprisonment. Already during this early chapter in the prison's history, regimes founding a new facility drew distinctions, not only between minor and major offenders or among socioeconomic strata but also between male and female inmates (Lansing 1997, 39-40; Geltner 2008d, 12, 18, 23; Kelleher 2010, 28). ${ }^{7}$ Prima facie, this was a prudent move given the potential for disorder, were men and women to occupy the same space. However, the very idea of joint albeit segregated facilities was innovative and even counterintuitive, especially given that women were rare in prison and the dangers they were thought to face there grave. Understandably, then, wardens' anxieties about effective separation were high, stemming on the one hand from their lack of experience in handling female inmates and on the other from the justice system's slow but steady processing of female offenders.

While medieval women were likely underrepresented in criminal statistics, they were far from absent. Even in the legally and procedurally diverse landscape of late-medieval Italy (Zorzi 1989; Dean 2007), female offenders are not hard to find. In Venice, for instance, women were involved in 17 percent (164 out of 962 ) of theft prosecutions between 1270 and 1347 , and in 14 percent (39 out of 274) between 1348 and 1403 (Piasentini 1992). ${ }^{8}$ In Florence, there was a significant rise in female involvement in

\footnotetext{
${ }^{6}$ The extent to which new urban facilities were meant to replace preexisting ecclesiastical ones is unclear. Episcopal palaces and mendicant convents held those prosecuted for and convicted of heresy, but not - or at least rarely—regular criminals.

${ }^{7}$ Barbara Hanawalt $(1974,265)$ asserts that "women and men were usually put into the same cell." Yet, even according to her source (Pugh 1968, 357-58), "the segregation of women was probably a good deal commoner than these [eight] instances imply."

${ }^{8}$ Stefano Piasentini offers imprecise percentages of "less than 20 " and "more than 12 " $(1992,88)$, so perhaps my tallying of his data, which include accomplices to crimes as well as main offenders, differs from his.
} 
theft from 1346, when one-third of the seventy-nine convicts were women (Caduff 1988). In Bologna, by contrast, women comprised only 3.4 percent $(47$ out of 1,382$)$ of all individuals accused of the offense between the mid-fourteenth and the late fifteenth centuries (Dean 2008). To move beyond theft: in 1346, 15 percent of all convicted criminals in Florence were women (Caduff 1988, 500); ${ }^{9}$ during a sample three-year period (1367-69) in Lucca, women were involved in 14 percent of all criminal cases (19 out of 134); ${ }^{10}$ and another sample study shows that women made up nearly 22 percent of all criminal defendants $(223$ out of 1,023$)$ before the onset of the Black Death in Florence, and still over 17 percent (40 out of 233) in its aftermath (Cohn 1996, 24-27). Thus, the emerging ballpark percentage of women's documented involvement in crime is far lower than men's, yet hardly marginal.

But if women were underrepresented in the courts, they were almost invisible in local prisons. Despite the fact that founding prisons enabled magistrates to incarcerate more people than ever before, women comprised a very small inmate minority. Three ( 14 percent) of the twenty-one inmates listed in Venice in 1393 were women, a figure that drops to zero in the two inmate traffic registers surviving from that period, for 1395 and $1400 .{ }^{11}$ Venice may have been an outlier, or else a total absence of women from the records might suggest that there was a separate register for female inmates. Yet even in the Florentine municipal prison, which is much better documented, female culprits constitute an average of 3 percent of all inmates, a significant decrease from their double-digit presence in criminal processes. ${ }^{12}$

Where did they all go? According to one data set, which comprises 201 sentences for women charged with theft in Venice between 1270 and 1403,120 offenders (51 percent) were whipped in various manners, and the majority of the rest ( 81 women; 40 percent) were mutilated. Eight women ( 4 percent) were executed, and three ( 1.5 percent) were exiled. A mere seven women (3.5 percent) received unspecified sentences, poten-

\footnotetext{
${ }^{9}$ Claudia Caduff (1988) supplies no exact figure. My numeric estimate is based on her statement that theft represented around 10 percent of all adjudicated crimes that year, involving fiftyfour cases and eighty-one defendants, although it remains unclear how many of those were convicted.

${ }^{10}$ Archivio di Stato di Lucca, Sentenze e Bandi 37-41.

${ }^{11}$ Archivio di Stato di Venezia, Avogaria di Comun 3645, fols. 1v-9r; and Soprastanti alle Carceri 1 and 2. There was a total of 268 inmates processing through the prison in the first instance and 176 in the second.

${ }^{12}$ Archivio di Stato di Firenze (ASF), Soprastanti alle Stinche (SS), Carceri e Carcerati (Carc.), 82-85, 88-91. Women imprisoned for debt in Paris in 1488-89 constituted 3.5 percent of female inmates (Claustre 2007, 265; see also Small 1993, 368-70).
} 
tially including incarceration. (The parallel figure for men is 13 ; 1 percent.) As was typical of conviction rates in the period, here too they were extremely high: none of the accused women were absolved, as compared with two men (0.2 percent) who were (Piasentini 1992). ${ }^{13}$ In Venice, then, sentenced female offenders were unlikely to spend much time in prison.

That said, the available records (and here Venice is typical of coeval citystates) do not allow us to stipulate a total or even substantial overlap between decreed and performed sentences. Actual punishments likely comprised higher rather than lower incarceration rates than would appear at first sight, since some culprits could commute fines into jail time. Thus, while court records attest women's limited presence behind bars, both as compared with that of men and as a proportion of women prosecuted for crime, they should be treated with caution. And it is with like scrutiny that we should consider the common opinion among medieval jurists against the use of punitive imprisonment, which made no gender distinctions (Geltner 2008d, 45-53).

The weak forces pushing women into prisons need to be seen in conjunction with the strong ones pulling them out. Even among those women who did find themselves behind bars, a high percentage (as compared with male inmates) were released as an act of charity. For while amnesty was in principle open to all convicts, it seems to have benefited women in particular. Female inmates are overrepresented in lists of oblates released on major feast days. In fourteenth-century Siena, for example, an average of 25 percent of inmates released on charitable grounds were women, probably far above their relative share in the general inmate population. ${ }^{14}$

Another important force drawing women away from prison was penal cloistering. Detrusio (literally, "a casting away"), or the practice of incarcerating laypeople in monasteries, has received little attention from scholars of premodern punishment (Goria 1974). Emperor Justinian introduced the earliest secular legislation concerning the measure between 542 and 556 , and in it he instructed Christian monks to host certain culprits in order to better their ways (Hillner 2007; Hatlie 2009). Justinian was prob-

${ }^{13}$ Punishments for accomplices are not always specified, hence the discrepancy between 203 and 201 penalties. See also Dean $(2001,118-43 ; 2007,198-99)$.

${ }^{14}$ Archivio di Stato di Siena, Consiglio Generale, Deliberazioni 99, fols. 119v-121r (April 11, 1324); 101, fols. 46r-49r (August 13, 1324), 183v-186r (December 24, 1324); 102, fols. $81 \mathrm{r}-82 \mathrm{v}$ (December 24, 1325); 106, fols. 22v-24r (August 12, 1328); 108, fols. 22v-25v (August 12, 1329), 91v-95r (December 22, 1329); 109, fols. 89v-92v (April 3, 1330); 120, fols. 53r-58v (April 10, 1337); 121, fols. 17r-20r (August 13, 1337); Offerte di Carcerati 470, fols. 2v-6v (December 23, 1337); 473, fols. 19r-25r (March-December 1361). On oblations in Siena and elsewhere, see Koenig (2001). 
ably concerned with elite laymen and the upper clergy. Yet he also sought to remove laywomen awaiting trial from local prisons to private dwellings or, in grave cases, nunneries, thereby paving the way for their penal cloistering. ${ }^{15}$ Later, and backed by growing church support for this bloodless penal measure (Geltner 2008b), secular rulers throughout Europe began employing nunneries to detain various female culprits. With urbanization, the practice migrated with monasteries, which theretofore had predominantly been rural institutions, to cities: in late thirteenth-century Bologna, for instance, women belonging to the outlawed Lambertazzi faction were placed under the custody of different abbesses in charge of urban nunneries. ${ }^{16}$

Italian urban regimes were thus not merely reluctant to prosecute, let alone convict women; when it came specifically to incarcerating convicted criminals, magistrates were intentionally slow to accommodate even those few female culprits who should have spent time behind bars. Moreover, compared with male offenders, female offenders were quick to obtain amnesty or were subjected to detrusio, despite the fact that the measure was supervised by the church. Urban governments' reliance on the church, however, was both shortsighted and short-lived, since it took the clerics' cooperation for granted. Legislators and judges alike worked under the assumption that nuns would either approve of the chance to improve the fate of wayward women or else were too weak to resist serving as surrogate custodians. Both premises, however, were false.

Bologna provides a striking illustration. In 1294, a local abbess petitioned the city council to end the practice of ordering female offenders to be enclosed in female convents. If the city is running its own prison, she argued, laywomen should be placed under custody there: so long as that was legally forbidden, Bologna's magistrates were making a mockery out of the law. The abbess's intention was probably not to teach the councilmen a lesson in state-building so much as to reduce her convent's maintenance costs and to fulfill her own pastoral duties. ${ }^{17}$ And in any case, her plea was overstated given that women were at least occasionally incarcerated in municipal facilities. ${ }^{18}$

15 Novel 134.9.1 (556) in Schoel and Kroll (1954, 684).

${ }^{16}$ Archivio di Stato di Bologna (ASB), Capitano del Popolo, Giudici del Capitano del Popolo 49, 20r (October 16, 1283); 94, fol. 5v (October 15-16, 1286). On the Lambertazzi’s fortunes, see Blanshei (2010).

${ }^{17}$ ASB, Governo, Riformagioni e Provvigioni, Riformagioni del consiglio del popolo e della massa 138, Registri III/1, fol. 9v (April 26, 1294).

18 ASB, Curia del Podestà, Libri Inquisitionum 14, 1, fol. 5v, mentions several prostitutes handed over to the guard of the upper prisons in 1288. ASB, Curia del Podestà, Accusationes $22 \mathrm{~B}, 12$, fols. $12 \mathrm{v}-14 \mathrm{v}$ (July 2-26, 1300) mentions a female inmate accused of trying to poison her husband. 
Yet it was not until 1328 that Bologna's new ruler, the papal legate Bertrand del Poggetto, ordered the construction of a new female ward adjacent to the communal-and so far mostly male-prison. And while we should not assume that one decree brought the practice of female detrusio to a halt, it certainly seems to have created a new administrative path of least resistance. More important, Del Poggetto's ruling was in tune with a broader regional trend: neither my own records nor those of numerous colleagues whom I have consulted contain any case of female detrusio for criminal offenses in any major Italian city during the fourteenth century. ${ }^{19}$

Given that there is no previous record of joint prison facilities in Bologna, and that female criminals were few, it is worth pausing to consider the legate's motivations for effecting this turning point, which, to repeat, was typical at least in Italy. Did changing the status quo by creating a new female ward stem from his desire for efficient, central rule? Or was the act meant primarily to safeguard the nuns' reputation, and by extension that of the church, by brushing the city's female undesirables into the commune's backyard? There is of course no necessary contradiction between the two motivations, provided that the church was willing to relinquish control over an emblematic and visible aspect of its disciplinary mission. If so, what we may be dealing with here is an important recognition on the legate's part concerning the church's changing role in the centralized city-state.

Understanding the church's particular role in shaping secular incarceration practices avoids giving it undue credit for setting a penal revolution in motion, as some early prison historians have done (Krauss 1895). After all, detrusio was a time-honored tradition, also enabled by bishops' exercising of their rights as secular lords. Moreover, it was only the church's oversight of female incarceration, and not its meting out of prison sentences generally, that was actually being relinquished. Perhaps in this case too the church found it expedient to align its agenda with that of the Italian city-state (Jones 1997, 423-40). ${ }^{20}$

From the perspective of urban secular regimes, however, women received a cell of their own since they were considered an easy target, low-

\footnotetext{
${ }^{19}$ Women did, however, flee to nunneries for other purposes (Casagrande 1988; Strocchia 2003).

${ }^{20}$ Ralph B. Pugh $(1968,358)$ asserts that in all the earliest foundations of independent wards for women, "the initiative . . came from ecclesiastics" and specifically notes that in Oxford the move was designed "to protect the morals rather of the men than of the women." The premise, however, is questionable. First, it assumes that incarceration was the church's rather than the municipality's prerogative, and second, it takes for granted that mixed incarceration was the first or default rather than a second stage in the development of female incarceration, after monastic detrusio.
} 
hanging fruit for an expanding and ambitious state. As we shall see, unlike gender separation in early nineteenth-century institutions, the latemedieval development underscored women's limited political agency. And although this process was accompanied by a grudging recognition of women's particular needs, establishing these wards was no protofeminist triumph. Thus, when medieval city-states identified the custodial, coercive, and especially punitive incarceration of women as a politically attractive option, they pursued it, just as they had maintained the practice of detrusio for decades and even centuries beforehand. Underlying the shift was the notion that, by parading deviant women, however few and far between, into centrally located prisons, governments could gesture simultaneously at their own sovereignty and at women's ideal-subordinate role. Indeed, in founding women's wards, Italian urban regimes reified the relations of dominance and dependence by reproducing "the structure of the distribution of [social and symbolic] capital" (Bourdieu 1977, 184).

As for female offenders themselves, they appear to have had little say about their monastic exodus, and they played a limited role in shaping the terms and conditions of their new form of confinement. For women received not cells but $a$ cell of their own - perhaps not quite what Virginia Woolf had in mind as a vehicle for empowerment. True, magistrates were blind neither to the diversity of female prisoners nor to their unique needs. Yet despite their social and criminal variety, which undergirded the classification of male prisoners into wards, female inmates were usually crammed into one, albeit separate and protected, space.

\section{Inmate life at Le Stinche's female ward}

Some of the finest vistas open onto medieval prison life are offered by the records of Le Stinche, for over five hundred years (ca. 1300-1833) Florence's main prison. Le Stinche remains the best-documented institution of its kind, with extant records produced by its wardens and external supervisors stretching back to the mid-fourteenth century. Prior to this prison's establishment, female culprits tended to be imprisoned at a nearby tower called the Pagliazza, possibly an intervening stage between detrusio and the use of a centralized facility (Magherini and Biotti 1992; Manikowska 1995; Geltner 2008c). ${ }^{21}$

Le Stinche was divided into several wards, including an infirmary and a separate space for the mentally ill. The compound was managed by a group

\footnotetext{
${ }^{21}$ The Pagliazza occasionally held male inmates. See ASF, Provvisioni (Prov.), Registri 6, 31 (June 5, 1296).
} 
of four to six wardens, several guards, and a number of service staff, including a janitor, a physician, and a priest. Some of these men lived inside the prison, and all of them were salaried public employees. The prison had an external supervisory committee, which monitored the personnel's and the inmates' conduct and visited the prison weekly in order to interview representatives of each ward. Untypically for coeval prisons, there was no on-site kitchen, which meant that inmates were fed daily by their families or charity officials. There was, however, a chapel, run by a priest from the adjacent church of San Simone, enabling inmates to participate in mass, confess, and hear sermons. Otherwise the prison lacked any form of programming, including organized labor, and the lack of structure occasionally took its toll on the inmates, some of whom turned to gambling and other dubious pastimes. But broadly speaking, Le Stinche seems to have been a tolerable place, with few attested deaths from disease or violence, infrequent escape attempts, and rare assaults on staff by inmates (Geltner 2008a; Klapisch-Zuber 2008).

Perhaps most crucial for understanding Le Stinche is the fact that it was originally conceived and run as a debtors' prison, that is, as a facility meant to force its residents to return their loans or pay their taxes or fines. That inmates could theoretically leave the prison behind at any moment explains the lack of structure and also justified exacting processing and service fees as a sort of self-inflicted further penalty. Since such payments (known in Florence as agevolatura) were prorated according to the sum one owed, they helped to reinscribe external social divides within the prison walls, given that wealthier men tended to contract greater debt or owe higher taxes. Whoever paid more expected that fact to be reflected in his level of accommodation and in the company he could keep in prison.

Shortly after its foundation, Le Stinche began to receive a growing number of poor inmates who were handed sub-rosa prison sentences, being unable rather than unwilling to pay the fines judges imposed on them. To claim that "the term 'poor prisoner' is really a tautology" in late medieval Italy is an exaggeration (Koenig 2001, 228), but things were certainly headed in that direction. What began as an institution meant to serve (or rather, gently push out) propertied private debtors and wealthy tax evaders came to house, at some financial loss, ever more long-term prisoners who often could not pay for their own upkeep, let alone improve their conditions of captivity. The gradual impoverishment or at least diversification of the prison population made grafting external social strata onto the prison's internal divisions and daily life even more desirable.

How did women fit into and cope with the realities of this institution? Three sets of documents in particular shed light on the matter: inmate traf- 
fic logs, the prison's account books, and the supervisory committees' reports. For the period prior to 1400 , there remain 8 examples of the first series, 15 of the second, and 108 of the third. Only 7 of the traffic registers are legible, and jointly they attest the presence of 131 female inmates: an average of 18.5 cases per administrative semester, or 37 cases per year. The scale of these figures is corroborated by the prison's fiscal registers, which cover different semesters during the same century and which attest the average annual presence of thirty-two women, ${ }^{22}$ and somewhat less directly by references in the city council's enactments (provvisioni) to female inmates who were eligible for or actually secured charitable amnesty. ${ }^{23}$ Jointly, these confirm that women were a small minority in prison. ${ }^{24}$

The registers also provide us with the contours of a group profile. Shaped by medieval law's tendency to describe women in terms of their relations to men (Kelleher 2010, 24-27), these records illuminate female inmates' ties with their surrounding community. Sixty-eight women (52 percent) are described as married, remarried, or widowed (uxor, uxor olim, vidua), suggesting a majority of past and mostly present normative relationships. A further seventeen prisoners (13 percent) are described as mature unmarried girls ( filia, filia olim), and thirteen women (nearly 10 percent) are identified as domestic servants (sclava, famula). While certainly more vulnerable than the first group, both of the latter categories are still defined in terms of their relationship to existing Florentine households (Origo 1955; Heers 1981; Romano 1991). Next, fifteen women (11 percent) are referred to as "lady" (domina) without specifying family ties, but who nonetheless (and like all other women mentioned so far) resided in the city. It is important to note that the title domina (or donna) in this context is not a default term for any mature and/or unmarried woman. Rather, the appellation had an element of dignity derived from a combination of an individual's age, wealth, occupation, and residential status. It would be wrong to think of this group as socioeconomically homogenous, but they certainly shared a high degree of social embeddedness.

By contrast, a final group comprising eighteen women (around 14 percent) are recorded by name only. Here the absence of a broader social reference suggests that these inmates were unable or unwilling to provide such information, or that their jailers were uninterested in it. Either way, it is not far-fetched to conjecture a lowly socioeconomic status and, perhaps

${ }^{22}$ ASF, SS, Entrata e Uscita (EU) 376 (1355): 15 female inmates; 380 (1359-60): 10; 381 (1362-63): 15; 382 (1367-68): 9; 388 (1376-77): 25; 394 (1395): 17.

${ }^{23}$ ASF, Prov., Registri 12, 96 (January 27, 1305): 10; 13, 93 (October 30, 1307): 14; 15, 30 (June 23, 1317): 14; 15, 185 (December 30, 1318): 4; 16, 40 (March 26, 1319): 8.

${ }^{24}$ ASF, SS, Carc. 82-84, 88-91. 
more important, a lack of stable local ties, via employment or kinship. As Carol Lansing $(2002,306)$ has shown in a slightly different context, medieval Italian maidens without marriage prospects were "neglected, of little interest to their kin," and thus likely to become victims or perpetrators of crimes (see Terpstra 2010). If so, the only surprising aspect of the Florentine evidence is this group's dearth in the prison records vis-à-vis the presence of mature, married, and embedded female inmates.

Other than two women identified as foreigners (one a debtor, the other accused of an unspecified but serious crime),${ }^{25}$ the registers provide no further details about the less embedded group except for the charges brought against them, and these too are sometimes opaque. Six among them were convicted of prostitution. ${ }^{26}$ Of the remaining twelve, three were debtors (making it a total of four for this category) $;^{27}$ two were held pro amendare, which usually denotes a corrective measure imposed by a paterfamilias upon children or servants, but apparently not in these cases ${ }^{28}$ two for uno processo, that is, pretrial custody (albeit on unspecified grounds); ${ }^{29}$ one for a major but unstated crime (as mentioned above); and three for minor but undecipherable reasons. ${ }^{30}$

How do these grounds compare with, on the one hand, those concerning female inmates generally and, on the other, with the prison's male population? The first major difference is the prominence of prostitutes among less embedded women: all six cases concerned such women, confirming prostitutes' tendency to be foreign-born, of low socioeconomic standing, or both, and the near-absence of male sex workers. ${ }^{31}$ A second difference is the prominence of debtors among more embedded women: there were thirty-nine female debtors, significantly more than among the less embedded women. Underlying this gap is socially embedded women's greater ability to contract debt through formal credit networks, be it di-

${ }^{25}$ ASF, SS, Carc. 84, fol. $111 \mathrm{r}$ (July 29, 1360); and 91, fol. 82v (January 5-24, 1396), respectively. On the relations between crime and urbanization, see Geremek (1987) and Farmer (2002).

${ }^{26}$ ASF, SS, Carc. 83, fol. 106v (August 4-9, 1359); and 91, fol. 84r (January 20-22, 1395).

${ }^{27}$ ASF, SS, Carc. 84, fols. 91v (June 26-27, 1360; 2 cases), and 126v (August 29-31, 1360).

${ }^{28}$ ASF, SS, Carc. 88, fol. 131r (March 19-30, 1375); 89, fol. 26v; and 90, fol. 21v (March 25, 1375-May 31, 1376).

${ }^{29}$ ASF, SS, Carc. 90, fols. 56v (May 15, 1376), and 67r (June 3-September 2, 1376).

${ }^{30}$ ASF, SS, Carc. 84, fols. 76r (May 21-June 10, 1360), 127v (August 31, 1360), and 129v (September 3-4, 1360).

${ }^{31}$ See Otis $(1985,63-66)$, Rossiaud (1998, 42-43), Karras (1996, 56-57, 143 n. 3), and Scarabello $(2006,39)$. 
rectly or, more likely, indirectly by inheriting debt from their husbands or fathers, as was the case with donna Orrevole, who was imprisoned in 1308 on account of a large sum owed by her late husband, ser Bonafede Villanelli, to his notary, Neri Orlandi. ${ }^{32}$ Incurring debts formally led to prosecution rather than to an ad hominem solution, which was typical of less embedded women, who usually borrowed from other women..$^{33}$ That said, in the context of the prison's overwhelmingly male population, gender tended to trump social embeddedness. If better connected women were somewhat more likely to be incarcerated for debt than less embedded women were, men generally were twice as likely as women to get into this particular bind. Prostitution, in contrast, was an entirely female crime, just as gambling and illicit carrying of arms were distinctly male offenses.

A third main difference is that all female prisoners who were taken into custody by the direct command ( $a b$ parte) of various commune officials, for instance the podesta and the capitano del popolo, were embedded women. We can reasonably assume that these cases were given some priority, an impression only strengthened by the arrest of local women by other executives such as the regulators of the mint and especially the Dieci della Libertà, a body established in 1372 to check factionalism among the city's political elites (Becker 1962). Between February and June 1376, the Dieci arrested no fewer than three "ladies" (donne), among whom, perhaps unsurprisingly given their relative vulnerability as well as their willingness to take greater risks, two were widows. ${ }^{34}$ In sum, despite strong gender barriers, Florentine women could be convicted of perpetrating a range of crimes, including fairly sophisticated offenses requiring forethought and at times ideological commitment (see table 1 ). ${ }^{35}$

The predominance of propertied male debtors at Le Stinche was instrumental in shaping the inmates' experiences. As the prison's typical paying residents, debtors expected a certain decorum in their handling, including the ability to distinguish themselves socially within the prison walls. In this sense, the unplanned emergence of a prison underclass only helped to graft external norms onto the inmates' social structure and routines. Even as they undermined the prison's financial and legal rationale, inmates who had no choice of accommodation, had weak networks of sup-

${ }^{32}$ ASF, Prov., Registri 14, 1, fols. 1v-4r (June 7, 1308).

${ }^{33}$ See Jehel (1975), Riemer (1985), Shatzmiller (1990), and Jordan (1993).

${ }^{34}$ ASF, SS, Carc. 89, fol. 108v; and 90, fols. 36v (February 1-April 12, 1376), 109r (February 1-18, 1376); and 91, fol. 79v (June 25-27, 1376). On widows, see Klapisch-Zuber (1985), Cabot (1996), and Cohn (1996, 117-19).

${ }^{35}$ Zedner $(1991,40)$ likewise found that Victorian women were charged with crimes that were "often planned, organized, and ... highly sophisticated ventures." 
Table 1. Charges Brought against Embedded and Less Embedded Women, and the Male Population at Le Stinche, 1348-96

\begin{tabular}{lcrrr}
\hline & $\begin{array}{c}\text { \% among Less } \\
\text { Embedded } \\
\text { Female } \\
\text { Inmates } \\
(\boldsymbol{N}=\mathbf{1 9})\end{array}$ & $\begin{array}{c}\text { \% among } \\
\text { Embedded } \\
\text { Female } \\
\text { Inmates } \\
\text { Grounds for Arrest }\end{array}$ & $\begin{array}{c}\text { \% among } \\
\text { General } \\
\text { Female } \\
\text { Inmates } \\
(\boldsymbol{N}=\mathbf{1 1 2})\end{array}$ & $\begin{array}{c}\text { \% among } \\
\text { Male } \\
\text { Inmates } \\
(\boldsymbol{N}=\mathbf{1 , 0 0 6})\end{array}$ \\
\hline Debt & $21(4)$ & $31(35)$ & $30(39)$ & $73(741)$ \\
Prostitution & $32(6)$ & $0(0)$ & $5(6)$ & $0(0)$ \\
Pro amendare & $10.5(2)$ & $13(14)$ & $12(16)$ & $3(34)$ \\
Uno processo & $10.5(2)$ & $10(11)$ & $10(13)$ & $1(12)$ \\
Avere et persona & $5(1)$ & $11(12)$ & $10(13)$ & $1.5(18)$ \\
Ab parte & $0(0)$ & $17(19)$ & $14(19)$ & $0(0)$ \\
Bene custodia & $5(1)$ & $13(15)$ & $12(16)$ & $15(153)$ \\
Unknown & $16(3)$ & $5(6)$ & $7(9)$ & $4.5(46)$ \\
Gambling and arms & $0(0)$ & $0(0)$ & $0(0)$ & $2(22)$ \\
$\quad$ Total & 100 & 100 & 100 & 100 \\
\hline
\end{tabular}

Source: Archivio di Stato di Firenze, Soprastanti alle Stinche, Carcerati 82-84, 88-91.

port, and depended on charity or limited public funds reminded others, by way of a contrary example, of their privileged status. Thus, purpose, government, layout, and location meant that the ties that bound medieval inmates to their social environment operated as an effective, if informal, check on prison staff and the inmates' conduct and helped make medieval prison life tolerable by providing for inmates' adequate material and mental conditions (Geltner 2008a). But how did this state of affairs affect Le Stinche's female inmates? ${ }^{36}$

Account books and the supervisory committee's interview reports reveal some anxiety over women's interaction with male inmates and the (all-male) staff, and its potential for danger and disorder. If, for instance, in 1349 the supervisors' charter was to investigate gambling and drinking as typical violations, already by 1366 that list had expanded to include prostitution and entry into the women's ward. ${ }^{37}$ The emphasis is noteworthy given that, unlike their male counterparts, female inmates lived behind several locks and were tended to by a lay friar, theoretically an emascu-

\footnotetext{
36 The contrast with modern US female inmates is striking. The latter are typically young, poor, uneducated single mothers from ethnic minorities or of foreign provenance, often with a history of mental illness and convicted of drug-related crimes (Glick and Neto 1977; Figueira-McDonough et al. 1981; Rafter 1983, 143-44; Dodge 2002, 110-24).

${ }^{37}$ ASF, Atti dell'Esecutore degli Ordinamenti di Giustizia (AEOG) 129 (1349) and 489 (1366).
} 
lated staff member. ${ }^{38}$ Still, the specter of heterosexual contact loomed large, despite the fact that the interviews themselves offer no evidence that the women's ward was ever breached. Nor is there any indication that female inmates had sex with one another, but, tellingly, such an activity was never designated as an offense.

The prison's account books attest that in 1367 , nine male inmates were fined 5 lire each for approaching the women's ward "to chat" (ad parlan$d u m)^{39}$ and that nine years later, another inmate, Nuccio Agnoli, was fined the same sum for the same offense. ${ }^{40}$ A meager yield, to be sure, perhaps even suspiciously so given Le Stinche's modest size and the inmates' proximity to one another. It is possible that the custodians' effective implementation of official policy, which was carefully scrutinized by an oversight committee, rendered both men's and women's willing compliance negligible. What is remarkable, however, is that, in contrast with their nineteenthcentury heirs, medieval female inmates were never held responsible "for any and all disruptions that their presence created within the masculine world of the penitentiary" (Dodge 1999, 909). That the default blame in such contexts was laid upon male inmates hardly sustains the view of medieval prisons as gender-aware spaces, but it does illustrate how institutional gender biases could take different forms.

A trickle of evidence suggests tension within the women's ward. On July 2, 1367, a certain donna Angela confided that she had seen two other inmates, donna Giovanna and donna Maxiana, conspiring against a fourth inmate, donna Tommasina. ${ }^{41}$ And on June 11, 1379, a brawl broke out between two female inmates, but no immediate context is provided. ${ }^{42}$ At least in these cases the events could not be concealed from the supervisory committee. But otherwise, documentary silence shrouds the social dynamics of Le Stinche's female ward. It is an odd silence, since it contrasts with the well-documented male-on-male violence in prison and even more so with urban women's common assaults on one another outside the prison walls (Spierenburg 2008, 114-42). ${ }^{43}$ However, that the prison actually had a restraining effect on its female inmates would come as no surprise to students

\footnotetext{
${ }^{38}$ Female guards or custodians are largely unknown before the nineteenth century (Freedman 1974, 79-80; Zedner 1998, 298-301).

${ }^{39}$ ASF, SS, EU 382, fol. 4r (October 30, 1367).

${ }^{40}$ ASF, SS, EU 382, fol. $\operatorname{lr}$ (October 4, 1376).

${ }^{41}$ ASF, AEOG 501, fols. 18v-19r (July 2, 1367).

${ }^{42}$ ASF, AEOG 1099, fol. 13v (June 11, 1389).

${ }^{43}$ Spierenburg $(2008,120)$ acutely notes the official dismissal of female-on-female aggression as not "real" violence.
} 
of the modern women's prison, who have repeatedly noted their fairly benevolent inmate subculture (Dalley 1993; Belknap 2007, 214).

This modest evidentiary basis provides us with some room to contemplate what incarceration meant specifically for late-medieval women. It suggests that Le Stinche's female inmates were relatively safe from physical harm. There is no mention of their harassment by staff, which is sometimes attested for other prisons, however sporadically. ${ }^{44}$ One wonders, of course, if the extant records in Florence and elsewhere conceal more than they reveal. Yet nowhere do they suggest a prevalence of sexual victimization at a level anywhere near its present state.

The focus on the frequency of women's sexual harassment by men in prison is perhaps unwarranted, however. After all, Le Stinche's female prisoners were placed under a triple lock and key, and their custodians would have been greatly neglectful in allowing such instances to become routine affairs. This is not to say that female inmates endured no pains of imprisonment but rather that these originated elsewhere. For apart from some physical discomforts, which they shared with some male inmates, women probably suffered the most from the socially undifferentiated space that they inhabited, and that reified an ideal category of deviant women. Both independently and vis-à-vis male prisoners, women's coerced egalitarianism must have been humiliating more than it was physically dangerous.

Nowhere else at Le Stinche, or for that matter in Florence, was the disregard for social status and criminal hierarchy as blatant as in the female ward. The discrepancy was hardly coincidental or merely numberdependent. As mentioned above, male inmates at Le Stinche and elsewhere could differentiate themselves through agevolatura. Yet women were barred from this mode of self-classification. Despite the diversity of their crimes and socioeconomic strata, Le Stinche's women tended to be embedded in the surrounding community. Being forbidden from distinguishing themselves in prison must have been devastating, first given inmates' continued interaction with their surrounding society, and second in view of the fact that their male counterparts were, if anything, encouraged to do so as part of the warden's strategy for maintaining order (Geltner 2008d, 63-67).

Giving women a cell of their own thus presents a unique, almost singular attempt to enforce an equality attendant upon liminality (Turner $1969,1977)$. The female ward contrasted sharply with the prison's adjacent male space, which was officially furnished with possibilities for social and criminal distinction. This extreme form of marginalization sought to

\footnotetext{
${ }^{44}$ For two cases of male staff sexually assaulting female inmates, see ASB, Curia del Podestà, Giudici ad Maleficia, Libri Inquisitionum 197, Reg. 4, fol. 83r-v (October 20, 1363); 203 Reg. 5, fols. 66r-68v (September 9, 1366).
} 
obliterate female inmates' extramural identity, not as a way to maintain order within the prison walls but rather to underscore the gross aberration of women's presence behind bars. Hence the double standard employed for men and women's safety: bringing together women from such different walks of urban life as domestic servants, prostitutes, merchants, and elite political rebels did not bode well for reducing friction in the female ward. Yet city magistrates and prison officials had no qualms about this apparent security hazard. It seems that maintaining women, and especially deviant women, as a fourth (or even fifth) estate was paramount.

\section{Reframing the history of female wards}

However limited, our knowledge about medieval women's incarceration sheds new light on the history of crime and punishment and on the social history of ideas concerning female deviance in particular. These and other fields can benefit from considering the role prisons and their regimens played in shaping penal practices for women and the extent to which these reflected both an understanding and (an ipso facto conscious) neglect of their needs.

In the fourteenth century, prisons emerged as an increasingly likely end to or at least a main station in some criminal prosecutions as well as private disputes managed by the state. And yet for complex reasons, including both the pattern of female crime and the biases inherent in its prosecution, women were even more grossly underrepresented in these new facilities than they were in coeval criminal courts. This appears to support modern assumptions regarding the prison's inherent maleness, which are projected and multiplied for premodern times. Yet that would be oversimplifying the conclusion to be drawn from this study. It remains unclear, for instance, to what extent the early prison helped discourage magistrates and law enforcers from arresting, prosecuting, and ultimately punishing women with imprisonment, thereby perpetuating the view of criminality in general and the prison in particular as an exclusively male domain. For, as we have seen, these facilities were not merely constructed by men and for men: women's wards were integrated immediately or at any rate soon after the establishment of new centralized facilities, and certain aspects of women's well-being preoccupied prison administrators.

At the same time, the apparent integration of women into public penal space and practices did not signal a budding legitimacy of female crime and deviance. Despite paying some attention to incarcerated women's specific needs (at least as they were understood by contemporary urban administrators), medieval prisons reified the notion that female offenders ought to be doubly penalized: once for their specific crime, and once again for 
disobeying a social script. Indeed, clapping all women - regardless of status or criminal offense-into one ward, as was done at Le Stinche and elsewhere, spotlighted that very point, and should be considered a subordinating gesture typical of medieval women's pains of incarceration.

Medieval female wards fit uneasily into modern models of reformed and unreformed prisons for further reasons. Beyond the functional differences between the two, neither the social profile nor the experiences of the women we have explored shares much with present-day realities. While the discrepancies in social constitution have to do with the putatively coercive goals of premodern incarceration, which rendered the imprisonment of propertied women more likely, these women's apparently tolerable experience is more difficult to account for in light of those small wards' social and criminal heterogeneity. Yet social and criminal desegregation, even when compounded by crowdedness and boredom, does not seem to have led to social implosion among female inmates.

There is not much more we can surmise about the group dynamics of medieval Italian female inmates. Perhaps they were their sisters' keepers; perhaps the prison's general visibility and accessibility alleviated part or most of the tensions attendant upon their state. Then again, the available records may conceal more than they reveal. At any rate, it seems that medieval practices of incarcerating women and women's experiences in these prisons significantly depart from assumptions too often made about them (Smith 1962; Burford and Shulman 1992, 138-62). Premodern prison experiences were neither as bleak nor as uniform as some scholars of modern prisons have imagined them to be. Nor can they be easily shoehorned into modern reformed or prereformed molds. On the one hand, they shared some characteristics of both gender-aware and gender-biased prison regimes; on the other - as is the case with coeval male prisons - it is impossible to identify a mainstream among their inmates' experiences (Turning $2010,11-13)$. But such idiosyncrasies should come as no surprise to the social historian. After all, as the early criminologist Alexandre Lacassagne $(1913,364)$ put it, "societies have the criminals they deserve."

Department of History

University of Amsterdam

\section{References}

Adler, Freda. 1975. Sisters in Crime: The Rise of the New Female Criminal. New York: McGraw-Hill.

Becker, Marvin B. 1962. "Church and State in Florence on the Eve of the Renaissance (1343-1382).” Speculum 37(4):509-27. 
Belknap, Joanne. 2007. The Invisible Woman: Gender, Crime, and Justice. 3rd ed. Belmont, CA: Thomson/Wadsworth.

Blanshei, Sarah Rubin. 2010. Politics and Justice in Late Medieval Bologna. Leiden: Brill.

Boffey, Julia. 1991. "Chaucerian Prisoners: The Context of the Kingis Quair." In Chaucer and Fifteenth-Century Poetry, ed. Julia Boffey and Janet Cowen, 84-99. London: King's College, Centre for Late Antique and Medieval Studies.

Bourdieu, Pierre. 1977. Outline of a Theory of Practice. Trans. Richard Nice. Cambridge: Cambridge University Press.

Burford, E. J., and Sandra Shulman. 1992. Of Bridles and Burnings: The Punishment of Women. New York: St. Martin's.

Cabot, Isabelle. 1996. “ ‘Sola, donna, non gir mai’: Le solitudini femminili nel TreQuattrocento" [Alone, a woman never goes: Female solitudes in the fourteenth and fifteenth centuries]. Memoria: Rivista di Storia delle Donne [Memory: Review of women's history], no. 18: 7-24

Caduff, Claudia. 1988. "I 'publici latrones' nella città e nel contado di Firenze a metà Trecento" [The "public thieves" in the city and hinterland of Florence in the mid-fourteenth century]. Ricerche storiche [Historical research], no. 18: 497-521.

Carlen, Pat. 1983. Women's Imprisonment: A Study in Social Control. London: Routledge/Kegan Paul.

Casagrande, Giovanna. 1988. "Il fenomeno della reclusione volontaria nei secoli del basso medioevo" [The phenomenon of voluntary reclusion in the centuries of the late Middle Ages]. Benedictina [Benedictine] no. 35: 475-507.

Chen, Gila, and Tomer Einat. 2010. Kele nashim: He-hatser ha-ahorit shel ha-hever be-Yiśra'el [Women's prison: The backyard of Israeli society]. Tel Aviv: Resling.

Chesney-Lind, Meda. 1986. "Women and Crime: The Female Offender." Signs: Journal of Women in Culture and Society 12(1):78-96.

Claustre, Julie. 2007. Dans les geôles du roi: L'emprisonnement pour dette à Paris à la fin $d u$ Moyen Age [In the king's jails: Imprisonment for debt in Paris at the end of the Middle Ages]. Paris: Publications de la Sorbonne.

Cohen, Esther. 1980. "Patterns of Crime in Fourteenth-Century Paris." French Historical Studies 11(3):307-27.

Cohn, Samuel K., Jr. 1996. Women in the Streets: Essays on Sex and Power in Renaissance Italy. Baltimore: Johns Hopkins University Press.

Conway, Alan, and Carol Bogdan. 1977. "Sexual Delinquency: The Persistence of a Double Standard." Crime and Delinquency 23(2):131-35.

Dalley, Bronwyn. 1993. "Following the Rules? Women's Responses to Incarceration, New Zealand, 1880-1920.” Journal of Social History 27 (Winter): 309-25.

Dean, Trevor. 2001. Crime in Medieval Europe, 1200-1550. Harlow: Longman.

- 2007. Crime and Justice in Late Medieval Italy. Cambridge: Cambridge University Press.

. 2008. "Theft and Gender in Late Medieval Bologna." Gender and History 20(2):399-415. 
Dodge, L. Mara. 1999. “'One Female Prisoner Is of More Trouble than Twenty Males': Women Convicts in Illinois Prisons, 1835-1896." Journal of Social History 32(4):907-30.

- 2002. "Whores and Thieves of the Worst Kind": A Study of Women, Crime, and Prisons, 1835-2000. DeKalb: Northern Illinois University Press.

Dunbabin, Jean. 2002. Captivity and Imprisonment in Medieval Europe, 10001300. London: Palgrave Macmillan.

Eisner, Manuel. 2003. "Long-Term Historical Trends in Violent Crime." Crime and Justice, no. 30: 83-142.

Farmer, Sharon. 2002. Surviving Poverty in Medieval Paris: Gender, Ideology, and the Daily Lives of the Poor. Ithaca, NY: Cornell University Press.

Feeley, Malcolm M., and Hadar Aviram. Forthcoming. "The Decline of Women in the Criminal Process, 1650-1900: A Comparative Assessment."

Feeley, Malcolm M., and Deborah L. Little. 1991. "The Vanishing Female: The Decline of Women in the Criminal Process, 1687-1912." Law and Society Review 25(4):719-57.

Figueira-McDonough, Josefina, Alfreda P. Iglehart, Rosemary Sarri, and Terry Williams. 1981. "Females in Prison in Michigan, 1968-1978: A Study of Commitment Patterns." Report, School of Social Work and the Institute for Social Research, University of Michigan.

Freedman, Estelle B. 1974. "Their Sisters' Keepers: An Historical Perspective on Female Correctional Institutions in the United States: 1870-1900." Feminist Studies 2(1):77-95.

Froissart, Jean. 1974. La prison amoureuse [The amorous prison]. Ed. Anthime Fourrier. Paris: Éditions Klincksieck.

Geltner, G. 2008a. “Coping in Medieval Prisons." Continuity and Change 23(1): $151-72$.

_. 2008b. "Detrusio: Penal Cloistering in the Middle Ages." Revue Bénédictine 118(1):89-108.

_. 2008c. "Isola non isolata: Le Stinche in the Middle Ages." Annali di Storia di Firenze [Annals of the history of Florence], no. 3: 7-28.

- 2008d. The Medieval Prison: A Social History. Princeton, NJ: Princeton University Press.

Geremek, Bronisław. 1987. The Margins of Society in Late Medieval Paris. Trans. Jean Birrell. Cambridge: Cambridge University Press.

Given, James B. 1977. Society and Homicide in Thirteenth-Century England. Stanford, CA: Stanford University Press.

Glick, Ruth M., and Virginia V. Neto. 1977. "National Study of Women's Correctional Programs." Report, National Institute of Law Enforcement and Criminal Justice, Washington, DC.

Goria, Fausto. 1974. "La Nov. 134, 10; 12 di Giustiniano e l'assunzione coattiva dell'abito monastico" [Justinian's Nov. 134, 10; 12 and coercive claustration]. In Studi in onore di Giuseppe Grosso [Studies in honor of Guiseppe Grosso], vol. 6, 55-76. Turin: G. Giappichelli. 
Gradowicz-Pancer, Nira. 2002. "De-gendering Female Violence: Merovingian Female Honour as an 'Exchange of Violence.' " Early Medieval Europe 11(1):1-18.

Hagan, John, John Simpson, and A. R. Gillis. 1988. "Feminist Scholarship, Relational and Instrumental Control, and a Power-Control Theory of Gender and Delinquency." British Journal of Sociology 39(3):301-36.

Hanawalt, Barbara, 1974. "The Female Felon in Fourteenth-Century England." Viator, no. 5: 253-68.

Hatlie, Peter. 2009. Monks and Monasteries of Constantinople (ca. 350-850). Cambridge: Cambridge University Press.

Heers, Jacques. 1981. Esclaves et domestiques au Moyen Age dans le monde méditerranéen [Slaves and domestics in the medieval Mediterranean world]. Paris: Fayard.

Hillner, Julia. 2007. “Monastic Imprisonment in Justinian's Novels.” Journal of Early Christian Studies 15(2):205-37.

Hutchinson, Virginia, Kristin Keller, and Thomas Reid. 2009. "Inmate Behavior Management: The Key to a Safe and Secure Jail.” Report, National Institute of Corrections, US Department of Justice. http://static.nicic.gov/Library/023882 .pdf.

James, Erwin. 2007. "No Place for a Lady." Guardian, November 30. http:// www.guardian.co.uk/society/2007/nov/30/prisonsandprobation.comment.

Jehel, Georges. 1975. "Le rôle des femmes et du milieu familial à Gênes dans les activités commerciales au cours de la première moitié du XIIIe siècle" [The role of women and the familial milieu in commercial activities in Genoa during the first half of the thirteenth century]. Revue d'histoire économique et sociale [Economic and social history review], no. 53: 193-215.

Jones, Philip. 1997. The Italian City-State: From Commune to Signoria. Oxford: Clarendon.

Jordan, William Chester. 1993. Women and Credit in Pre-industrial and Developing Societies. Philadelphia: University of Pennsylvania Press.

Karras, Ruth Mazo. 1996. Common Women: Prostitution and Sexuality in Medieval England. New York: Oxford University Press.

Kasprzyk, Krystyna. 1988. “L'expérience de la prison et de l'exil chez quelques poètes de la fin du moyen âge" [The experience of prison and exile among some poets of the late Middle Ages]. In La souffrance au moyen âge (France, XIIe-XVes.) [Suffering in the Middle Ages (France, twelfth to fifteenth centuries)], ed. Elżbieta Grabska, Barbara Grochulska, Nicole Taillade, and Janina Kulczycka-Saloni, 165-79. Warsaw: Éditions de l'Universite de Varsovie.

Kelleher, Marie A. 2010. The Measure of Woman: Law and Female Identity in the Crown of Aragon. Philadelphia: University of Pennsylvania Press.

Klapisch-Zuber, Christiane. 1985. "The 'Cruel Mother': Maternity, Widowhood, and Dowry in Florence in the Fourteenth and Fifteenth Centuries." In Women, Family, and Ritual in Renaissance Italy, trans. Lydia Cochrane, 117-31. Chicago: University of Chicago Press.

- 2008. "The Devil in Prison." In Power, Gender, and Ritual in Europe and the Americas: Essays in Memory of Richard C. Trexler, ed. Peter Arnade and 
Michael Rocke, 95-111. Toronto: Centre for Reformation and Renaissance Studies.

Koenig, John. 2001. "Prisoner Offerings, Patron Saints and State Cults at Siena and Other Italian Cities from 1250 to 1550." Bullettino senese di storia patria [Sienese bulletin of homeland history], no. 108: 222-96.

Krauss, F. A. Karl. 1895. Im Kerker vor und nach Christus [In prison before and after Christ]. Freiburg: Mohr.

Kruttschnitt, Candace, and Rosemary Gartner. 2003. "Women's Imprisonment." Crime and Justice, no. 30: 1-81.

Lacassagne, Alexandre. 1913. "Les transformations du droit pénal et les progrès de la médecine légale, de 1810 à 1912" [Transformations in penal law and progress in legal medicine, 1810-1912]. Archives d'anthropologie criminelle [Archives of criminal anthropology], no. 28: 321-64.

Lansing, Carol. 1997. "Gender and Civic Authority: Sexual Control in a Medieval Italian Town." Journal of Social History 31(1):33-59.

—. 2002. "Girls in Trouble in Late Medieval Bologna." In The Premodern Teenager: Youth in Society, 1150-1650, ed. Konrad Eisenbichler, 293-309. Toronto: Centre for Reformation and Renaissance Studies.

Lesselier, Claudie. 1984. "Les femmes et les prisons, 1829-1939: Prisons de femmes et reproduction de la société patriarcale" [Women and prisons, 1829-1939: Women's prisons and the reproduction of patriarchal society]. In La prison, le bagne et l'histoire [Prisons, penal colonies, and history], ed. Jacques Petit, 115-28. Paris: Éditions Médecine et Hygiène.

Magherini, Graziella, and Vittorio Biotti. 1992. L'Isola delle Stinche e i percorsi della follia a Firenze nei secoli XIV-XVIII [The Isola delle Stinche and the course of madness in Florence, fourteenth to eighteenth centuries]. Florence: Ponte alle Grazie.

Manikowska, Halina. 1995. "The Florentine Communal Prison-Le Stinche - in the Fourteenth Century." Acta Poloniae Historica [Historical acts of Poland], no. 71 133-60.

Margolis, Nadia. 1978. “The Human Prison: The Metamorphosis of Misery in the Poetry of Christine de Pizan, Charles d'Oreleans, and François Villon." In Fifteenth-Century Studies, ed. Guy R. Mermier and Edelgard E. DuBruck, 185-92. Kalamazoo, MI: Medieval Institute Publications.

Marshall, Ineke Haen. 1983. “The Women's Movement and Female Criminality in the Netherlands." In Comparative Criminology, ed. Israel L. Barak-Glantz and Elmer H. Johnson, 87-102. Beverly Hills, CA: Sage.

Means, Michael H. 1972. The Consolatio Genre in Medieval English Literature. Gainesville: University of Florida Press.

Menage, René. 1978. "Deux poètes en prison: Maître Jean Régnier et le prisonnier desconforté du château de Loches" [Two poets in prison: Maître Jean Régnier 
and the unhappy prisoner of the Castle of Loches]. In Exclus et systemes d'exclusion dans la littérature et la civilisation médiévales [Systems of exclusion and the excluded in medieval literature and civilization], 239-49. Aix-en-Provence: CUERMA.

Meneghetti, Maria Luisa. 1992. "Scrivere in carcere nel medioevo" [Writing in prison in the Middle Ages]. In Studi di filologia e letteratura italiana in onore di Maria Picchio Simonelli [Studies in philology and Italian literature in honor of Maria Picchio Simonelli], ed. Pietro Frassica, 185-99. Alessandria: dell'Orso.

Mooney, Linne R., and Mary-Jo Arn, eds. 2005. The Kingis Quair and Other Prison Poems. Kalamazoo, MI: TEAMS.

Musurillo, Herbert, ed. and trans. 1972. The Acts of the Christian Martyrs. Oxford: Clarendon.

Neville, Cynthia J. 1998. "War, Women and Crime in the Northern English Border Lands in the Later Middle Ages." In The Final Argument: The Imprint of Violence on Society in Medieval and Early Modern Europe, ed. Donald J. Kagay and L. J. Andrew Villalon, 163-75. London: Boydell.

Origo, Iris. 1955. "The Domestic Enemy: The Eastern Slaves in Tuscany in the Fourteenth and Fifteenth Centuries." Speculum 30(3):321-66.

Otis, Leah Lydia. 1985. Prostitution in Medieval Society: The History of an Urban Institution in Languedoc. Chicago: University of Chicago Press.

Peters, Edward M. 1995. "Prison before the Prison: The Ancient and Medieval Worlds." In The Oxford History of the Prison: The Practice of Punishment in Western Society, ed. Norval Morris and David J. Rothman, 3-43. Oxford: Oxford University Press.

Piasentini, Stefano. 1992. "Alla luce della luna”: I furti a Venezia (1270-1403) ["In the light of the moon": Thefts in Venice (1270-1403)]. Venice: Il Cardo.

Pollak, Otto. 1950. The Criminality of Women. Philadelphia: University of Pennsylvania Press.

Pugh, Ralph B. 1968. Imprisonment in Medieval England. Cambridge: Cambridge University Press.

Rafter, Nicole Hahn. 1983. "Prisons for Women, 1790-1980." Crime and Justice, no. 5: 129-81.

—. 1985. "Gender, Prisons, and Prison History." Social Science History 9(3): $233-47$.

Riemer, Eleanor S. 1985. "Women, Dowries, and Capital Investment in ThirteenthCentury Siena." In The Marriage Bargain: Women and Dowries in European History, ed. Marion A. Kaplan, 59-79. New York: Haworth.

Romano, Dennis. 1991. "The Regulation of Domestic Service in Renaissance Venice." Sixteenth Century Journal 22(4):661-77.

Rossiaud, Jacques. 1988. La prostitution médiévale [Medieval prostitution]. Paris: Flammarion. 
Scarabello, Giovanni. 2006. Meretrices.: Storia della prostituzione a Venezia tra il XIII e il XVIII secolo [Prostitutes: A history of prostitution in Venice between the thirteenth and eighteenth centuries]. Venice: Supernova.

Schoel, Rüdolf, and Wilhelm Kroll, eds. 1954. Corpus Iuris Civilis [The corpus of civil law]. Vol. 3. Berlin: Weidmann.

Shapiro, Ann-Louise. 1996. Breaking the Codes: Female Criminality in Fin-de-Siècle Paris. Stanford, CA: Stanford University Press.

Shatzmiller, Joseph. 1990. Shylock Reconsidered: Jews, Moneylending, and Medieval Society. Berkeley: University of California Press.

Simon, Rita James. 1975. Women and Crime. Lexington, MA: Lexington.

Sims, Richard J. 2005. "Secondary Offenders? English Women and Crime, c. 1220 1348." In Victims or Viragos?, ed. Christine Meek and Catherine Lawless, 69-88. Dublin: Four Courts.

Small, Carola M. 1993. "Prisoners at the Castellany of Artois in the Early Fourteenth Century." Histoire Sociale-Social History 26(52):344-72.

Smith, Ann D. 1962. Women in Prison: A Study in Penal Methods. London: Stevens \& Sons.

South, Scott J., and Steven F. Messner. 1987. "The Sex Ratio and Women's Involvement in Crime: A Cross-National Analysis." Sociological Quarterly 28(2): $171-88$.

Spierenburg, Pieter. 1991. The Prison Experience: Disciplinary Institutions and Their Inmates in Early Modern Europe. New Brunswick, NJ: Rutgers University Press.

- 2008. A History of Murder: Personal Violence in Europe from the Middle Ages to the Present. Cambridge: Polity.

Strocchia, Sharon T. 2003. "Taken into Custody: Girls and Convent Guardianship in Renaissance Florence." Renaissance Studies 17(2):177-200.

Summers, Joanna. 2004. Late-Medieval Prison Writing and the Politics of Autobiography. Oxford: Oxford University Press.

Teilmann, Katherine S., and Pierre H. Landry Jr. 1981. "Gender Bias in Juvenile Justice." Journal of Research in Crime and Delinquency 18(1):47-80.

Terpstra, Nicholas. 2010. Lost Girls: Sex and Death in Renaissance Florence. Baltimore: Johns Hopkins University Press.

Trombetta, Simona. 2004. Punizione e caritá: Carceri femminili nell'Italia dell'Ottocento [Punishment and charity: Female prisons in nineteenth-century Italy]. Bologna: Il Mulino.

Turner, Victor W. 1969. The Ritual Process: Structure and Anti-structure. Chicago: Aldine.

1977. "Variations on a Theme of Liminality." In Secular Ritual, ed. Sally Falk Moore and Barbara G. Meyerhoff, 36-52. Assen: Van Gorcum.

Turning, Patricia. 2010. "The Right to Punish: Jurisdictional Disputes between Royal and Municipal Officials in Medieval Toulouse." French History 24(1):1-19.

Walker, Garthine. 1994. "Women, Theft and the World of Stolen Goods." In Women, Crime and the Courts in Early Modern England, ed. Jenny Kermode and Garthine Walker, 81-89. London: Methuen. 
Wright, Kevin. 1988. "Improving Correctional Classification, New York, 19811983." Report, Inter-university Consortium for Political and Social Research, Ann Arbor, MI. http://www.icpsr.umich.edu/icpsrweb/ICPSR/studies/8437.

Zedner, Lucia. 1991. Women, Crime, and Custody in Victorian England. Oxford: Clarendon.

1998. "Wayward Sisters: The Prison for Women." In The Oxford History of the Prison: The Practice of Punishment in Western Society, ed. Norval Morris and David J. Rothman, 295-324. Oxford: Oxford University Press.

Zorzi, Andrea. 1989. "Giustizia criminale e criminalità nell'Italia del tardo medioevo: Studi e prospettive di ricerca" [Criminal justice and criminality in late medieval Italy]. Società e storia [Society and history], no. 46: 923-65. 